\title{
Water-Quality Assessment within a Drainage Control District in Southeastern Florida
}

The U.S. Geological Survey (USGS) began an extensive ground- and surfacewater quality study in July 1989 to define the baseline water quality within a southeastern Florida drainage district and to develop a data base for future waterresource planning and management. Results were published in a USGS report (Lietz, 1996), comparing ground- and surface-water quality data (1989-94) to the Florida Department of Environmental Regulation Class I drinking-water standards. This Fact Sheet presents an additional 4 years of water-quality data and summarizes water-quality trends over the entire 10-year sampling period (1989-98) for selected sites and constituents.

\section{Development of the Southeastern Florida Drainage District}

The focus of this Fact Sheet is the South Indian River Water Control District, which is located within the northern Midlands area of Palm Beach County in southeastern Florida (fig. 1). Development of this District, originally known as the South Indian River Drainage District, began during the 1920's with the construction of drainage canals used for agricultural production. Development continued through the 1960's and 1970's with the sale of land for residential sites and with the construction of access roads. In 1983, surface-water improvements to the District's drainage basin (fig. 2, east of the C-18 canal) were implemented. Today (2000), agriculture has been displaced by very low to low density residential housing as the dominant land use in the northern Midlands area.

The South Indian River Water Control District is divided physically and hydraulically into an east basin and a west basin by the $\mathrm{C}-18$ canal (fig. 2). West of this canal, seven parallel canals (C-1 to C-7), spaced at 0.5-mile intervals from north to south, convey water east to the $\mathrm{C}-14$ canal, which flows northward to the

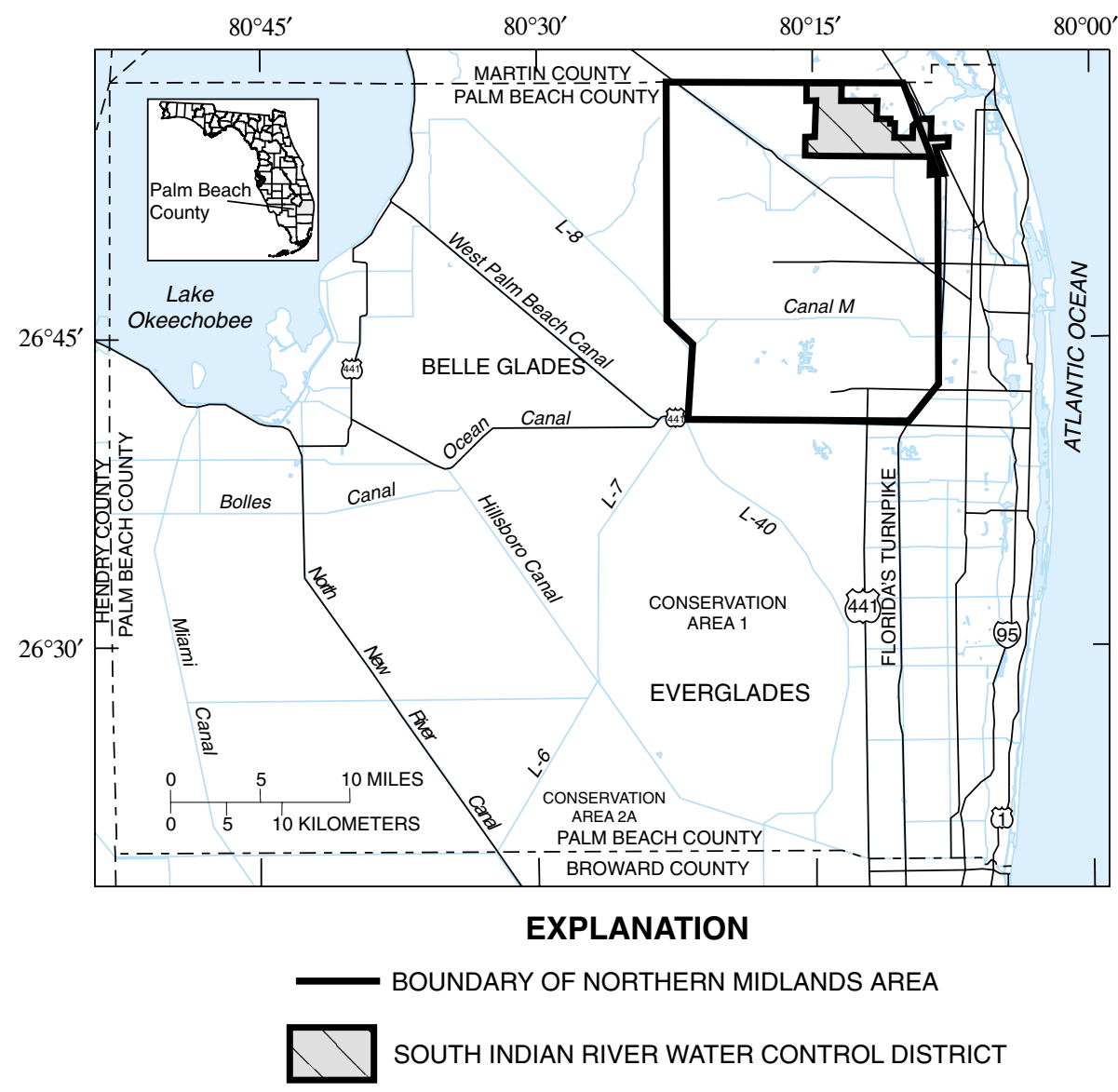

Figure 1. Location of the South Indian River Water Control District within the Midlands area of Palm Beach County, southeastern Florida.

Northwest Fork of the Loxahatchee River. The Lainhart Dam acts as a control structure for water flowing in the $\mathrm{C}-14$ canal. Stages in the C-18 canal generally are maintained higher than those in the C-14 canal, and water flows by way of gravity through control structure G-92 to the $\mathrm{C}-14$ canal. East of the $\mathrm{C}-18$ canal, seven canals (A-G) convey water in an easterly direction to the Header Canal, which transports water to the Turnpike Borrow Canal. Both the Header Canal and the Turnpike Borrow Canal extend in a northwest direction parallel to Florida's Turnpike. Water traverses weirs in canals A, C, D, and E before entering the Header Canal. Two other canals ( $\mathrm{J}$ and
H) east of the C-18 canal convey water west to the Turnpike Borrow Canal. Water in the Turnpike Borrow Canal flows in a north-northwest direction and then parallels the C-18 canal in a northnortheast direction and enters the Southwest Fork of the Loxahatchee River downstream of control structure S-46.

\section{Concern for Potable Water Supply}

The population of the northern Midlands area has grown in recent years with this trend expected to continue, resulting in increased demand for potable 


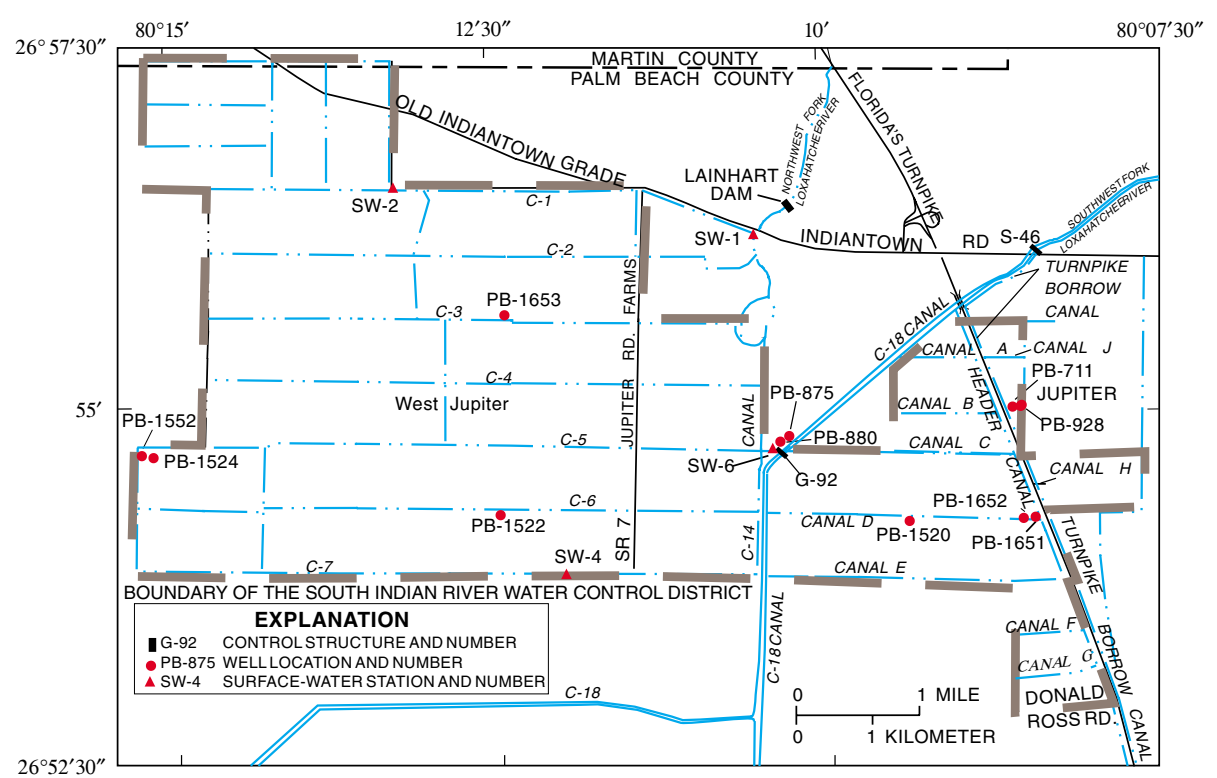

Figure 2. Location of wells, surface-water sites, major roads, canals, and control structures within the South Indian River Water Control District. water and increased need for waste disposal. No public-water supplies presently exist in the area; therefore, many residents must rely on private wells for domestic water supplies and on septic tanks for waste disposal. Additionally, pockets of residual seawater that have been incompletely flushed from the surficial aquifer system (the principal source of freshwater for southeastern Florida) exist in the western part of the northern Midlands (Miller, 1991, p. 12), possibly rendering the water unsuitable for domestic use.

The availability of a potable water supply is of utmost concern to water officials and concerned citizens.

\section{Methods and Analytical Procedures}

In the initial study between July 1989 and August 1994 (Lietz, 1996), water samples were collected both monthly and quarterly from 11 wells and 14 surfacesis was made to determine concentrations of major inorganic constituents and other related physical characteristics, trace metals, nitrogen and phosphorus species, and synthetic organic compounds. These water-quality data were used to determine which constituents exceeded the State of Florida drinking-water standards (Florida Department of Environmental Protection, 1993). Water-quality sampling continued from October 1994 to September 1998, providing a total of 10 years of continuous water-quality data for all 11 wells and 4 of the surface-water stations. No surface-water stations in the east basin contained data of sufficient length of time for trend analysis. water stations in the study area. An analy-
A series of boxplots (figs. 3-6) have been generated to illustrate the maximum, minimum, 1st quartile (25th percentile), median (50th percentile), 3rd quartile (75th percentile), and outliers for dissolved solids, total nitrogen, and total phosphorus at selected sites. The ends of the box represent the 25th and 75th percentiles (also known as the interquartile range). The median (or 50th percentile) is represented by a horizontal white line in the box. Horizontal lines, connected by dashed vertical lines extending from the ends of the box, represent outer fences that indicate the extent of data beyond the quartiles. Horizontal lines extending beyond the fences represent outliers.

The ESTREND computer program (Schertz and others, 1991) was the principal statistical tool employed for the determination of water-quality trends over the 10-year period. To ascertain the anthropogenic (manmade) effects on water quality over time, extraneous variation in water-quality data must be compensated for; this variation may be the result of seasonality, discharge, or waterlevel changes. To compensate for seasonal effects, a test called the Seasonal Kendall trend test was employed. This test makes pairwise comparisons of data values from the same seasons and then combines the results into the Seasonal Kendall test statistic. Extraneous variations caused by discharge or waterlevel changes may be negated by performing a procedure called linear regression analysis on the data. This procedure compensates for the effects of discharge and water-level changes on water-quality data by developing relations between the specific constituent concentrations in question and the discharge or water-level data. This test results in flow-adjusted or water-level adjusted concentrations, commonly referred to as residuals. The Seasonal Kendall trend test is then applied to these residuals as well as to the unadjusted concentrations to determine the best trend. The Seasonal Kendall slope estimator, which presents the rate of change in original units (milligrams per liter) per year and percent per year, is the median of all the pairwise comparisons from all the seasons.

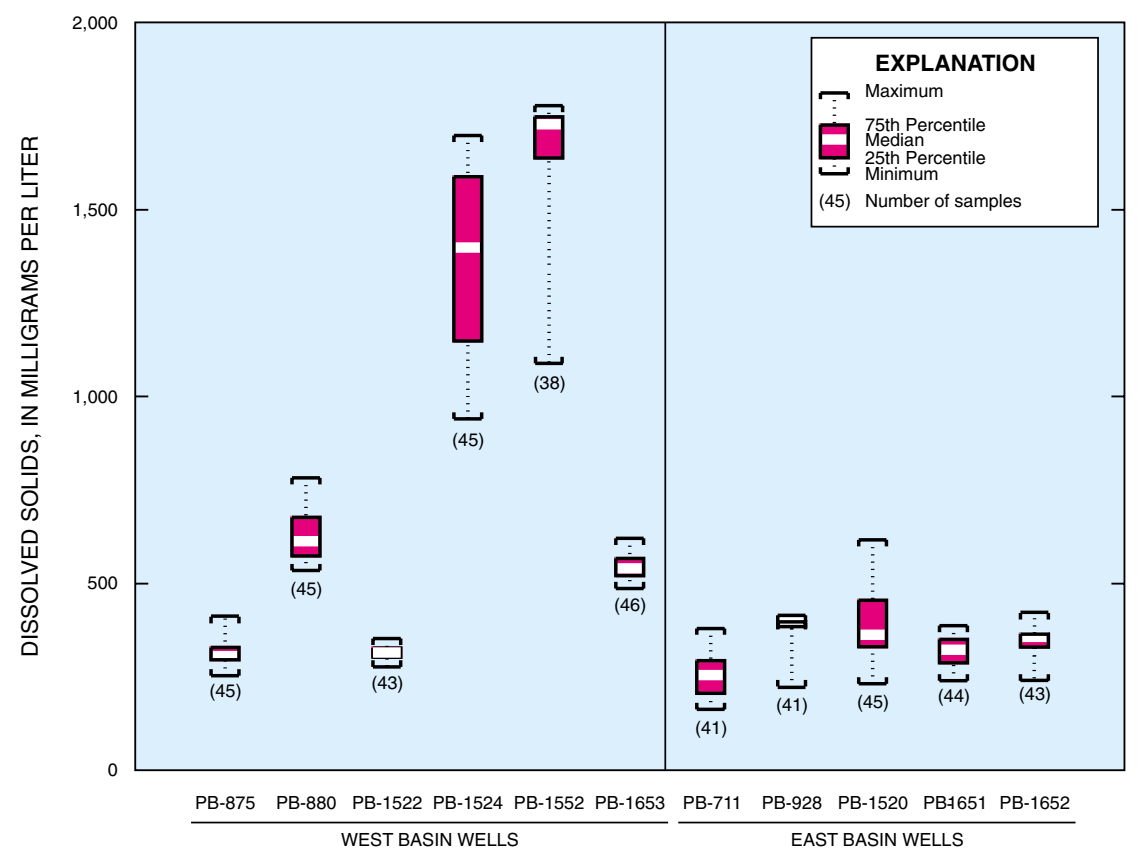

Figure 3. Dissolved-solids concentrations from wells in the east-west basin of the South Indian River Water Control District, 1989-98. 


\section{Water-Quality Data and Trends}

A trend analysis of selected waterquality constituents collected from 11 wells and 4 surface-water stations was made for the South Indian River Water Control District from 1989 to 1998. The east basin of the District is represented by wells PB-711, PB-928, PB-1520, $\mathrm{PB}-1651$, and $\mathrm{PB}-1652$; the west basin is represented by wells PB-875, PB-880, PB-1522, PB-1524, PB-1552, PB-1653 and surface-water stations SW-1, SW-2, SW-4, and SW-6 (fig. 2).

Comparisons of dissolved-solids, total nitrogen, and total phosphorus concentrations were made between ground-water wells and surface-water stations in the study area during 1989-98. There was, however, insufficient data for nitrogen and phosphorous species at the ground-water wells for any trends or statistical comparisons. Median concentrations of dissolved solids were higher in the west basin than in the east basin (fig. 3). Among the six wells in the west basin (fig. 3), PB-1552 had the highest median dissolved-solids concentration of $1,730 \mathrm{mg} / \mathrm{L}$ (milligrams per liter); this is because highly mineralized residual seawater exists in western Palm Beach County (Miller, 1991, p. 12). In the west basin, the lowest median dissolvedsolids concentration of $307 \mathrm{mg} / \mathrm{L}$ was detected in well PB-875. Among the wells in the east basin (fig. 3), the highest median dissolved-solids concentration of $364 \mathrm{mg} / \mathrm{L}$ was detected in well PB-1520, and the lowest $(256 \mathrm{mg} / \mathrm{L})$ was detected in well PB-711.

A comparison of dissolved-solids concentrations among the four surface-water stations (SW-1, SW-2, SW-4, and SW-6) in the west basin is shown in figure 4 . The highest median concentration $(350 \mathrm{mg} / \mathrm{L})$ was detected at SW-4, and the lowest (264 mg/L) was detected at SW-6.

A comparison of total nitrogen concentrations among the surface-water stations is shown in figure 5 . The highest median concentration $(0.99 \mathrm{mg} / \mathrm{L})$ was detected at SW-6; this value was below the median total nitrogen concentration of $1.2 \mathrm{mg} / \mathrm{L}$ for Florida streams as determined during 1970-87 (Friedeman and Hand, 1989).

The lowest median concentration $(0.76 \mathrm{mg} / \mathrm{L})$ was detected at SW-2.

A comparison of total phosphorus concentrations among the four surfacewater stations is shown in figure 6. The highest median concentration $(0.03 \mathrm{mg} / \mathrm{L})$ was detected at stations SW-1, SW-2, and SW-4; this value was below the median total phosphorus concentration of $0.13 \mathrm{mg} / \mathrm{L}$ for rivers across the Nation (Smith and others, 1987) as well as below the median concentration of $0.11 \mathrm{mg} / \mathrm{L}$ for Florida streams

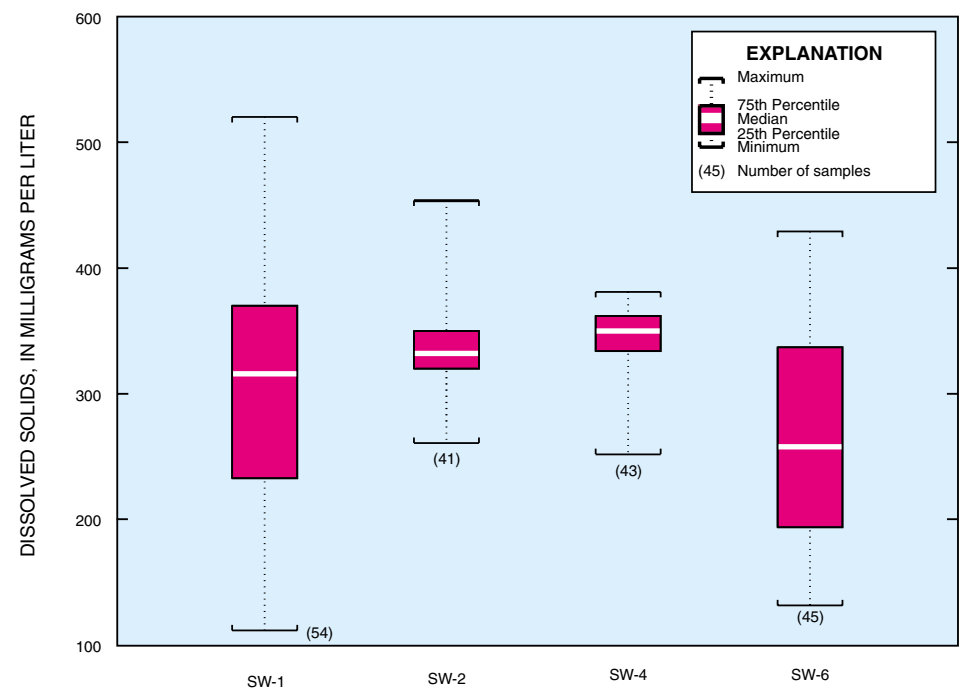

Figure 4. Dissolved-solids concentrations from surface-water sites in the South Indian River Water Control District 1989-98.

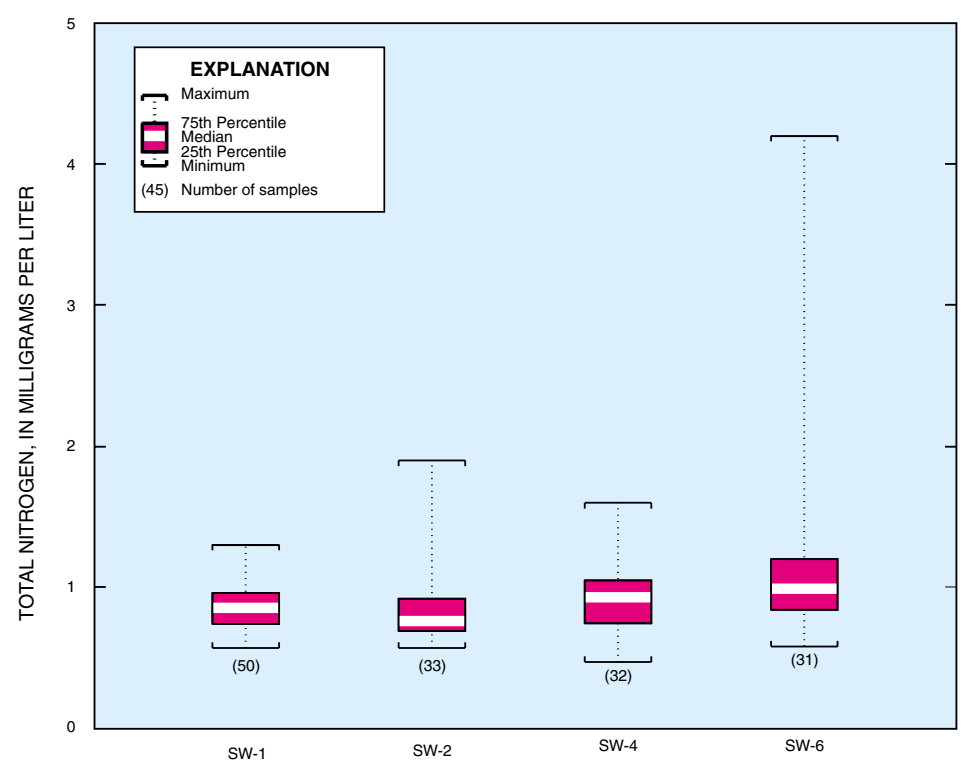

Figure 5. Total nitrogen concentrations from surface-water sites in the South Indian River Water Control District 1989-98.

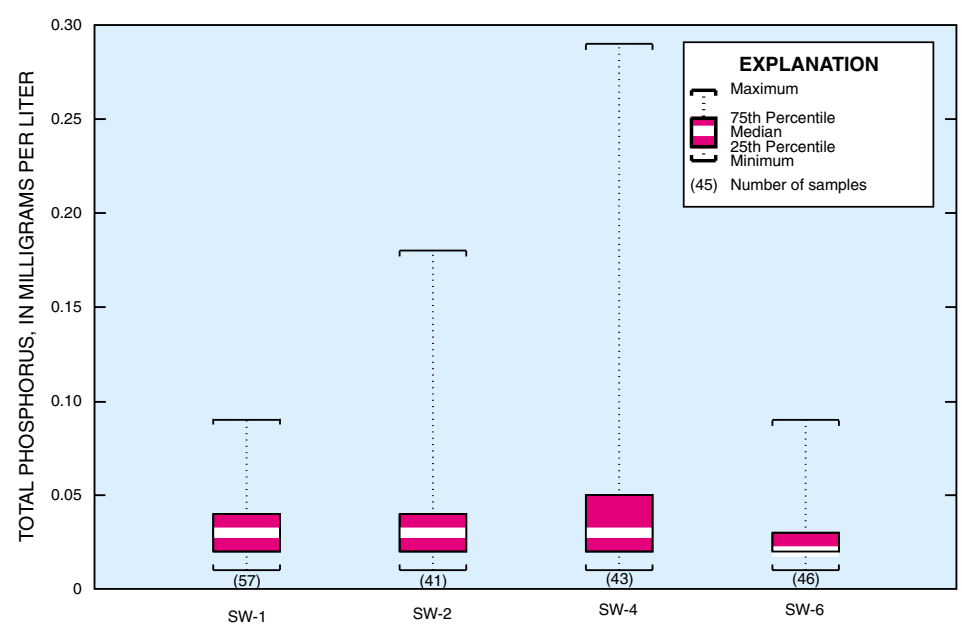

Figure 6. Total phosphorus concentrations from surface-water sites in the South Indian River Water Control District 1989-98. 
determined during 1970-87 (Friedeman and Hand, 1989). The lowest median concentration $(0.02 \mathrm{mg} / \mathrm{L})$ was detected at SW-6. Station SW-6 exhibited the greatest variation in total phosphorus concentrations for all of the surfacewater stations.

Those sampling sites and constituents that showed statistically significant trends ( $p$-values less than 0.10), based on division into the east and west basins, are summarized in table 1 . In 1989-98, 9 of the 15 statistically significant trends were detected for dissolved solids. In ground water, four upward (increasing) trends in dissolved solids were detected in the east basin, three upward trends in the west basin, and one downward (decreasing) trend in the west basin (table 1). One downward trend for dissolved solids in surface water was detected in the west basin. Additionally, two downward trends for ammonia plus organic nitrogen, two upward trends for nitrite plus nitrate nitrogen, one upward trend for total phosphorus, and one downward trend for total organic nitrogen in surface water were detected in the west basin.

Increases in constituent concentrations may result from urbanization or agricultural activities. Generally, downward trends for specific constituents, especially dissolved solids and nitrogen and phosphorus species, indicate an improvement in water quality with time; whereas upward trends for these same constituents indicate a general deterioration in water quality with time (table 1).

\section{Extent of Water-Quality Changes and Future Monitoring Plans}

Trend results indicate that deterioration in water quality has occurred in the east basin as evidenced by the four upward trends in dissolved solids. Because no water samples were analyzed for nitrogen or phosphorus species in the east basin, no conclusions concerning changes in water quality based on these constituents can be made. In the west basin, 6 of 11 trends were determined to be upward trends. These upward trends included three for dissolved solids and three for nitrogen species. However, there were also two downward trends for dissolved solids and three downward trends for nitrogen species in the west basin. Obviously, some deterioration in water quality has occurred in the west basin based on results of overall dissolvedsolids trends. However, the three upward trends (nitrite plus nitrate and total phosphorus) in nitrogen and phosphorus

Table 1. Statistically significant ( $p$-value less than 0.10 ) trends for selected constituents and their effect on water quality, 1989-98

$[\mathrm{N}$, number of observations used for trend determination; NH4+Org, ammonia plus organic nitrogen; W, water-level adjusted concentration; U, unadjusted concentration; F, flowadjusted concentration]

\begin{tabular}{|c|c|c|c|c|c|c|c|}
\hline \multirow{2}{*}{$\begin{array}{l}\text { Well or } \\
\text { station } \\
\text { number }\end{array}$} & \multirow[t]{2}{*}{ Constituent } & \multirow[t]{2}{*}{$\mathbf{N}$} & \multicolumn{2}{|c|}{$\begin{array}{c}\text { Increase or } \\
\text { decrease (-) per } \\
\text { year in constituent } \\
\text { concentration }\end{array}$} & \multirow{2}{*}{$\begin{array}{c}\text { Significance } \\
\text { level } \\
\text { (p-value) }\end{array}$} & \multirow[t]{2}{*}{$\begin{array}{c}\text { Type of } \\
\text { trend }\end{array}$} & \multirow[t]{2}{*}{$\begin{array}{c}\text { Effect on } \\
\text { water quality }\end{array}$} \\
\hline & & & $\begin{array}{c}\text { Milligrams } \\
\text { per liter }\end{array}$ & Percent & & & \\
\hline \multicolumn{8}{|c|}{ East Basin } \\
\hline PB-711 & Dissolved solids & 31 & 10.09 & 3.98 & 0.004 & $\mathrm{~W}$ & Deterioration \\
\hline PB-928 & Dissolved solids & 31 & 2.04 & .52 & .044 & $\mathrm{~W}$ & Deterioration \\
\hline PB-1520 & Dissolved solids & 36 & 20.61 & 5.09 & .076 & W & Deterioration \\
\hline PB-1652 & Dissolved solids & 34 & 5.58 & 1.61 & .063 & $\mathrm{U}$ & Deterioration \\
\hline \multicolumn{8}{|c|}{ West Basin } \\
\hline PB-880 & Dissolved solids & 33 & 11.67 & 1.84 & .036 & $\mathrm{U}$ & Deterioration \\
\hline PB-1522 & Dissolved solids & 36 & 5.33 & 1.68 & .000 & $\mathrm{U}$ & Deterioration \\
\hline PB-1524 & Dissolved solids & 35 & 80.00 & 5.83 & .000 & $\mathrm{U}$ & Deterioration \\
\hline PB-1653 & Dissolved solids & 36 & -10.00 & -1.83 & .000 & $\mathrm{U}$ & Improvement \\
\hline \multirow{2}{*}{ SW-1 } & NH4+Org & 31 & -.02 & -2.08 & .055 & $\mathrm{~F}$ & Improvement \\
\hline & Nitrite plus nitrate & 34 & .01 & 12.07 & .001 & $\mathrm{U}$ & Deterioration \\
\hline SW-2 & Nitrite plus nitrate & 37 & .01 & 8.90 & .067 & $\mathrm{U}$ & Deterioration \\
\hline \multirow{2}{*}{ SW-4 } & Total phosphorus & 35 & .00 & 6.70 & .065 & $\mathrm{U}$ & Deterioration \\
\hline & Dissolved solids & 31 & -3.45 & -1.00 & .032 & $\mathrm{U}$ & Improvement \\
\hline \multirow{2}{*}{ SW-6 } & NH4+Org & 32 & -.03 & -2.99 & .076 & $\mathrm{~F}$ & Improvement \\
\hline & Total organic nitrogen & 27 & -.03 & -3.67 & .021 & $\mathrm{~F}$ & Improvement \\
\hline
\end{tabular}

species would indicate deterioration in water quality, and the three downward trends (ammonia plus organic nitrogen and total organic nitrogen) would indicate improvement in water quality.

Based on the water-quality trend results from this study, future monitoring plans may need to include a more concentrated sampling effort directed toward analysis of constituents for which upward trends exist and a less intensive effort toward sampling for all constituents. An annual sampling of major inorganic constituents and physical characteristics, total nitrogen species, and total phosphorus species could be performed with more frequent (possibly monthly or quarterly) sampling of selected constituents that show upward trends at specific sites.

\section{Selected References}

Florida Department of Environmental Protection, 1993, Drinking water standards, monitoring and reporting: Chapter 17-550, Florida Administrative Code, $38 \mathrm{p}$.

Friedeman, Mark, and Hand, Joseph, 1989, Typical water-quality values for Florida's lakes, streams, and estuaries: Florida Department of Environmental Regulation Report, 23 p.

Helsel, D.R., and Hirsch, R.M., 1992, Statistical methods in water resources: Amsterdam, Elsevier Publishers, 529 p.

Lietz, A.C., 1996, Assessment of water quality in the South Indian River Water Control District, Palm Beach County, Florida, 1989-94: U.S. Geological Survey Open-File Report 96-495, 63 p.

Miller, W.L., 1991, Hydrogeology and migration of septic tank effluent in the surficial aquifer sys- tem in the northern Midlands area, Palm Beach County, Florida: U.S. Geological Survey WaterResources Investigations Report 91-4175, 69 p.

Schertz, T.W., Alexander, R.B., and Ohe, D.J., 1991, The computer program estimate trend (ESTREND), a system for the detection of trends in water-quality data: U.S. Geological Survey Water Resources Investigations Report 91-4040, $63 \mathrm{p}$.

Smith, R.A., Alexander, R.B., and Wolman, M.G., 1987, Water-quality trends in the Nation's rivers: Science, March 27, 1987, v. 235, p. 1607-1615.

Smith, R.A., Hirsch, R.M., and Slack, J.R., 1982, A study of trends in total phosphorus measurements at NASQAN stations: U.S. Geological Survey Water-Supply Paper 2190, 34 p.

By A.C. Lietz.

This Fact Sheet supplements a USGS publication titled "Assessment of Water Quality in the South Indian River Water Control District, Palm Beach County, Florida, 1989-94" (USGS Open-File Report 96-495). For information, contact:

$$
\text { Clint Lietz }
$$

U.S. Geological Survey 9100 N.W. 36th Street, Suite. 107

Miami FL 33178

phone: (305) 717-5800

fax: (305) 717-5801

e-mail: alietz@usgs.gov

Additional copies of this report can be obtained from:

U.S. Geological Survey

Branch of Information Services Box 25286

Denver, CO 80225-0286 888-ASK-USGS

Information about water resources in Florida is available on the World Wide Web at http://fl.water.usgs.gov 